\title{
STRATEGI PEMBERDAYAAN LAHAN PERTANIAN DAN PERKEBUNAN GUNA MENINGKATKAN KESEJAHTERAAN MASYARAKAT DI KECAMATAN PETIR KABUPATEN SERANG PROVINSI BANTEN
}

\author{
Oleh \\ Murdiyana \\ Institut Pemerintahan Dalam Negeri \\ murdiyana62@gmail.com
}

\begin{abstract}
Indonesia as an agrarian nation places the agriculture and plantation sector as a buffer for 1 meeting the needs of the community, bearing in mind that rapid population growth causes the growing demand for food, so as an effort to increase welfare of the community it is important to improve the effective ways in the strategy of empowering agricultural and plantation lands. This research on the topic of agricultural and plantation land empowerment, aims to find out and analyze the role of the Government in empowering agriculture and plantation lands for the community as well as analyzing the factors that encourage and hinder the community in empowering agricultural and plantation land in Kecamatan Petir Kabupaten Serang.

In order to improve the welfare of the community in Kecamatan Petir Kabupaten Serang, this study focuses in obtaining a real description of the strategy of agricultural and plantation land empowerment using descriptive methods with a qualitative approach. Data were obtained using an observation, interview methods and analyzed with "SWOT" analysis, namely strength, weakness, opportunity and threat.

Based on the results of the analysis that the strategy of empowering agricultural and plantation lands is appropriate and good enough. In quantity, there is already a lot of idle land that can be utilized as optimal as possible to increase the amount of harvest, thereby encouraging the awareness in the community, especially in the productive age to keep preserving agriculture and plantations.
\end{abstract}

Keywords: strategy, empowerment, agriculture, plantation and community welfare

\begin{abstract}
Abstrak
Indonesia sebagai negara agraris menempatkan sektor pertanian dan perkebunan sebagai penyangga bagi pemenuhan kebutuhan masyarakat, mengingat meningkatnya jumlah penduduk menyebabkan semakin terus bertambahnya kebutuhan akan pangan, maka dalam upaya menaikkan kesejahteraan masyarakat penting kiranya meningkatkan cara efektif dalam strategi pemberdayaan lahan pertanian dan perkebunan. Penelitian dengan topik pemberdayaan lahan pertanian dan perkebunan ini, bertujuan untuk mengetahui dan menganalisis peranan Pemerintah dalam pemberdayaan lahan untuk masyarakat di bidang pertanian dan perkebunan serta menganalisis faktor-faktor yang mendorong dan menghambat masyarakat dalam memberdayakan lahan pertanian dan perkebunan di Kecamatan Petir Kabupaten Serang.
\end{abstract}


Guna meningkatkan kesejahteraan masyarakat di Kecamatan Petir Kabupaten Serang, penelitian ini berfokus untuk memperoleh gambaran nyata tentang strategi pemberdayaan lahan pertanian dan perkebunan menggunakan metode deskriptif dengan pendekatan kualitatif. Data dikumpulkan menggunakan metode observasi dan wawancara serta dianalisis menggunakan analisis SWOT, yaitu strength (kekuatan), weakness (kelemahan), opportunity (peluang) dan threat (ancaman).

Berdasarkan hasil analisis bahwa strategi pemberdayaan lahan pertanian dan perkebunan sudah sesuai dan cukup baik. secara kuantiatif, sudah banyak lahan tidur yang dapat dimanfaatkan seoptimal mungkin untuk meningkatkan jumlah panen, sehingga mendorong munculnya kesadaran pada masyarakat khususnya di usia produktif untuk tetap melestarikan pertanian dan perkebunan.

Kata kunci: strategi, pemberdayaan, pertanian, perkebunan dan kesejahteraan masyarakat

\section{PENDAHULUAN}

$\mathrm{L}$ ahan merupakan salah satu sumber daya alam yang tidak terbaharui (unrenewable). Hampir semua sektor pembangunan fisik membutuhkan lahan (Sitorus 1998). Notohadinegoro (2000) menjelaskan, lahan kering adalah lahan yang berada di suatu wilayah yang berkedudukan lebih tinggi yang diusahakan tanpa penggenangan air. Selanjutnya, Rukmana (2001) menegaskan, lahan kering merupakan sebidang lahan yang dapat digunakan untuk usaha pertanian dengan menggunakan air secara terbatas dan biasanya bergantung pada air hujan. Sementara itu, Abdurachman et al. (2008) mendefinisikan lahan kering sebagai salah satu agroekosistem yang mempunyai potensi besar untuk usaha pertanian, baik tanaman pangan, hortikultura (sayuran dan buahbuahan) maupun tanaman tahunan dan peternakan.

Minardi (2009) menyatakan, lahan kering umumnya selalu dikaitkan dengan pengertian usaha tani bukan sawah yang dilakukan oleh masyarakat di suatu daerah aliran sungai (DAS) bagian hulu sebagai lahan atas atau lahan yang terdapat di wilayah kering (kekurangan air) dan bergantung pada air hujan. Berdasarkan
Atlas Arahan Tata Ruang Pertanian Indonesia skala 1: 1.000.000 (Puslitbangtanak 2001), Indonesia memiliki daratan sekitar 188,20 juta ha, terdiri atas 148 juta ha lahan kering (78\%) dan 40,20 juta ha lahan basah (22\%). Namun, Abdurachman et al. (2008) menyatakan, pemanfaatan lahan kering untuk pertanian sering diabaikan oleh para pengambil kebijakan yang lebih tertarik pada peningkatan produktivitas lahan sawah, padahal lahan kering tersedia cukup luas dan berpotensi untuk dikembangkan. Hal ini tidak menutup kemungkinan untuk terjadi di Provinsi Banten khususnya di Kecamatan Petir Kabupaten Serang.

Provinsi Banten khususnya Kabupaten Serang secara keseluruhan mempunyai luas wilayah sebesar $1.467,35 \mathrm{~km}^{2}$, di mana sebagian besar wilayahnya berupa dataran rendah dengan ketinggian kurang dari 500 $\mathrm{m}$ dan terdapat pula pegunungan (antara 0-1.778 m dpl). Dengan luas wilayah tersebut Kabupaten Serang terbagi menjadi 29 kecamatan, salah satunya adalah Kecamatan Petir yang memiliki luas wilayah berukuran sedang, yaitu 46,94 $\mathrm{km}^{2}$ dengan luas lahan pertanian di Kecamatan Petir sebesar 5.159 hektar terdiri dari 1.667 hektar lahan pertanian, 1.569 hektar lahan pertanian bukan sawah dan 1.933 hektar lahan bukan pertanian. Kecamatan Petir merupakan wilayah pembangunan bagian selatan dari 
Kabupaten Serang yang diarahkan dengan fungsi utama sebagai daerah Pertanian. Oleh karena itu mayoritas mata pencarian penduduk Kecamatan Petir adalah petani.

Wilayah Kecamatan Petir berada pada ketinggian antara 70 s.d. $86 \mathrm{~m}$ dari permukaan laut (dpl), dengan kondisi tanah berbukit dan bergelombang serta tanah merah dan liat/halus, maka secara topografi Kecamatan Petir pada umumnya tergolong pada kelas lahan dataran sedang dengan kemiringan lahan sedang berkisar antara $15^{\circ}-25^{\circ}$ dan merupakan wilayah tadah hujan. Suhu udara di Kecamatan Petir Kabupaten Serang selama tahun 2016 berkisar antara 23,4$31,8^{\circ} \mathrm{C}$ dengan kelembapan udara maksimal 91\%. Hujan turun di setiap bulannya dengan jumlah hari dan curah hujan dalam setahun masing-masing 147 hari dan 97,4 mm.

Di wilayah Kecamatan Petir sudah mengenal sistem irigasi sehingga air hujan yang turun di atas permukaan tanah akan menjadi aliran air yang mengalir melalui irigasi guna memenuhi kebutuhan lahan pertanian. Namun karena kondisi alamnya yang kurang bersahabat untuk pertanian dan di Kecamatan Petir belum terdapat badan air untuk menampung air pada musim hujan, kelebihan air akan langsung masuk ke dalam sungai dan mengalir ke laut. Hal ini menjadi kendala setiap tahun di saat musim kemarau. Kondisi lainnya dari permasalahan sumber daya alam yang ada di Kecamatan Petir ini, yaitu untuk kualitas tanah yang bisa dikategorikan sebagai lahan kritis. Hal ini dikarenakan sifat-sifat fisik tanah di Kecamatan Petir khususnya struktur dan tekstur tanah lebih dominan kepada lahan oxisol yang merupakan tanah yang kaya akan zat besi dan alumunium oksida. Kondisi tanah seperti ini umumnya memiliki solum yang dangkal dan ketebalan hanya kurang dari 1 meter, dengan warnanya merah hingga kuning dan memiliki tekstur halus seperti tanah liat. Akibatnya, dengan tanah bertekstur halus sampai sangat halus mempunyai efisiensi pemakaian air lebih tinggi dibandingkan dengan tanah yang bertekstur kasar, sehingga tanaman tidak atau kurang mampu menyerap air dengan baik karena penyerapan air oleh tanaman terhambat. Selain itu, pada tanah tersebut, infiltrasi air ke dalam tanah umumnya sangat lambat, sehingga air hujan yang jatuh di atas permukaan tanah banyak mengalir sebagai aliran permukaan. Kondisi tersebut pada akhirnya dapat mengakibatkan pemakaian air oleh tanaman tidak efisien dan tanah kurang subur. Hal ini menjadi kendala bagi masyarakat di Kecamatan Petir yang memang mengandalkan hidupnya melalui pertanian dan perkebunan. Untuk itu diperlukan restorasi lahan agar mendapatkan struktur tanah yang sehat sehingga produktivitas panen yang dihasilkan lebih optimal. Namun hal tersebut juga menjadi kendala bagi para petani di Kecamatan Petir, karena untuk melaksanakan restorasi lahan diperlukan pupuk yang jumlahnya tidak sedikit. Setidaknya, setiap 1 hektar lahan yang akan direstorasi diperlukan pupuk \pm 250 $300 \mathrm{~kg}$ Urea dan $\pm 150 \mathrm{~kg}$ SP 18 dicampur dengan \pm 3-5 ton/ha/tahun yang diberikan setelah pengolahan tanah pertama untuk meningkatkan efisiensi pupuk an organik. Hal ini tentu memberatkan bagi para petani di Kecamatan Petir khususnya pengadaan pupuk organik, apalagi bila dikaitkan dengan modal dan kemampuan yang ada serta tingkat pendapatan yang mereka peroleh saat ini, sehingga hal tersebut membuat sebagian lahan masyarakat di Kecamatan Petir belum dapat dimanfaatkan sebagai lahan pertanian maupun perkebunan secara maksimal.

\section{Rumusan Masalah}

Berdasarkan latar belakang
permasalahan di atas, maka dapat
dirumuskan permasalahan penelitian ini,
yaitu "Bagaimana strategi pemberdayaan
lahan pertanian dan perkebunan guna
meningkatkan kesejahteraan masyarakat di
Kecamatan Petir Kabupaten Serang?"




\section{TINJAUAN PUSTAKA}

Strategi merupakan alat untuk mencapai tujuan, dalam pengembangannya konsep mengenai strategi harus terus mengalami perkembangan dan setiap orang memiliki pendapat dan definisi mengenai strategi. Strategi adalah tindakan potensial yang membutuhkan keputusan manajemen tingkat atas dan sumber daya perusahaan dalam jumlah besar. Menurut David (2011: 18-19) Strategi adalah sarana bersama dengan tujuan jangka panjang yang hendak dicapai. Strategi adalah aksi potensial yang membutuhkan keputusan manajemen puncak dan sumber daya perusahaan dalam jumlah besar. Jadi strategi adalah sebuah tindakan aksi atau tindakan yang dilakukan oleh seseorang atau perusahaan untuk mencapai sasaran atau tujuan yang telah ditetapkan.

Menurut Tjiptono (2006: 3) istilah strategi berasal dari bahasa Yunani yaitu, Strategia yang artinya seni atau ilmu untuk menjadi seorang Jenderal. Strategi juga dapat dijadikan suatu rencana untuk pembagian dan penggunaan kekuatan militer pada daerah daerah tertentu untuk mencapai tujuan tertentu. Menurut Stoner, Freeman dan Gilbert. Jr (2005) Konsep strategi dapat didefinisikan berdasarkan dua perspektif berbeda, yaitu: (1) perspektif apa suatu organisasi ingin dilakukan (Intens To Do), dan (2) Perspektif apa organisasi akhirnya lakukan (Eventually Does). Dari definisi tersebut dapat disimpulkan bahwa strategi adalah hal yang ingin dilakukan untuk mencapai tujuan yang telah ditetapkan sebelumnya.

Banyak alternatif strategi yang dipilih untuk pengembangan usaha dalam berbagai bentuk. Alternatif tersebut di antaranya: strategi integrasi, strategi intensif, strategi diversifikasi dan strategi definisi.

\section{Pemberdayaan}

Menurut Rijono dan Ranarka (1996: 77) menyatakan bahwa pemberdayaan mengandung dua arti. Pengertian yang pertama adalah to give power of authority, pengertian kedua adalah to give ability to or enable. Pengertian pertama meliputi memberikan kekuasaan, mengalihkan kekuatan atau mendelegasikan otoritas kepada pihak yang kurang atau kurang berdaya. di sisi lain pemaknaan pengertian kedua adalah memberikan kemampuan atau keberdayaan memberikan peluang kepada pihak lain untuk melakukan sesuatu. Berbeda dengan pendapat Pranarka, Sumodiningrat (Sumodiningrat, 2000 dalam Ambar Teguh, 2004: 78-79) menyampaikan: pemberdayaan sebenarnya merupakan istilah yang khas Indonesia daripada Barat. di Barat istilah tersebut diterjemahkan sebagai empowerment, dan istilah itu benar tidak tepat. Pemberdayaan yang dimaksud adalah memberi "daya" bukan kekuasaan daripada pemberdayaan itu sendiri. Barangkali istilah yang paling tepat adalah energize atau katakan memberi energi pemberdayaan adalah pemberian energi agar yang bersangkutan mampu untuk bergerak secara mandiri. Bertolak pada kedua pendapat di atas dapat dipahami bahwa untuk konteks barat apa yang disebut dengan empowerment lebih merupakan pemberian kekuasaan daripada pemberian daya. Pengertian tersebut sangat wajar terbentuk, mengingat lahirnya konsep pemberdayaan di barat merupakan sesuatu reaksi dan pergulatan kekuasaan, sedangkan dalam konteks Indonesia apa yang disebut dengan pemberdayaan merupakan suatu usaha untuk memberikan daya, atau meningkatkan daya (Tri Winarni, 1998: 7576).

Pemberdayaan memiliki membangkitkan sumber daya, kesempatan, pengetahuan dan keterampilan masyarakat untuk meningkatkan kapasitas dalam menentukan masa depan mereka (Suparja dan Hempri, 2003: 43). Konsep utama yang terkandung dalam pemberdayaan adalah bagaimana memberikan kesempatan yang luas bagi masyarakat untuk menentukan sendiri arah kehidupan dalam komunitasnya. Konteks pemberdayaan 
sebenarnya terkandung unsur partisipasi, yaitu bagaimana masyarakat dilibatkan dalam proses pembangunan, dan hak untuk menikmati hasil pembangunan. Pemberdayaan mementingkan adanya pengakuan subjek akan kemampuan atau daya (power) yang dimiliki objek. Secara garis besar, proses ini melihat pentingnya mengalihfungsikan individu yang tadinya objek menjadi subjek (Suparjan dan Hempri, 2003: 44)

\section{Tujuan Penelitian}

Maksud dari pelaksanaan penelitian ini adalah untuk memecahkan permasalahanpermasalahan yang ada saat ini, khususnya tentang pemberdayaan sumber daya alam (SDA) di bidang pertanian dan perkebunan di wilayah Kecamatan Petir Kabupaten Serang. Dengan tujuan agar dapat diketahui strategi pemberdayaan lahan pertanian dan perkebunan guna meningkatkan kesejahteraan masyarakat di Kecamatan Petir kabupaten serang.

\section{METODE PENELITIAN}

Dalam penelitian ini, Penulis mempergunakan pendekatan kualitatif, di mana memperlakukan gejala yang menjadi kajian sasaran penelitian sebagai suatu sistem dan menyeluruh. Oleh karenanya penekanan terletak pada interpretasi dan kontekstual, serta masalah penelitian menekankan pada pemahaman masyarakat tentang metode interpretasi yang bersumber pada teori yang relevan.

Metode penelitian yang digunakan adalah metode deskriptif kualitatif, yaitu bertujuan untuk mendapatkan gambaran nyata tentang strategi pemberdayaan lahan pertanian dan perkebunan guna meningkatkan kesejahteraan masyarakat di Kecamatan Petir Kabupaten Serang.

\section{Teknik Pengumpulan Data}

Teknik pengumpulan data dalam penelitian ini dengan cara mengumpulkan data primer dan sekunder yang berkaitan dengan masalah yang dibahas. Menurut Creswell (2013: 266) menjelaskan bahwa teknik pengumpulan data meliputi langkahlangkah mengumpulkan informasi melalui observasi dan wawancara baik yang terstruktur maupun tidak, dokumentasi, materi-materi visual, serta usaha merancang protokol untuk merekam/mencatat informasi.

Dalam penelitian ini peneliti menggunakan teknik pengumpulan data yang merupakan kombinasi dari beberapa sumber, yaitu:

\section{- Sumber Data Primer}

Data primer adalah data yang diperoleh langsung dari sumbernya dan masih bersifat mentah karena belum diolah. Data ini diperoleh melalui:

\section{- Pengamatan/observasi.}

Pengamatan/observasi adalah pengamatan dan pencatatan yang sistematis terhadap fenomena-fenomena yang diteliti. Dalam pengamatan ini, peneliti terjun langsung ke lokasi penelitian dan melakukan pengamatan langsung terhadap objek-objek yang diteliti. Kemudian dari pengamatan tersebut dilakukan pencatatan data-data yang diperoleh yang berkaitan dengan aktivitas penelitian. Observasi dalam penelitian ini adalah observasi partisipatif atau terang-terangan. Peneliti berterus terang kepada sumber data sehingga pihakpihak yang diteliti mengetahui sejak awal sampai akhir tentang aktivitas peneliti.

\section{- Wawancara}

Peneliti menggunakan teknik ini untuk studi pendahuluan yang diharapkan dapat menemukan permasalahan yang harus diteliti. Wawancara ini juga tidak menutup kemungkinan apabila peneliti ingin mengetahui hal-hal dari informan yang lebih mendalam. Konsep yang diungkapkan menurut Creswell (2013: 267), peneliti dapat 
melakukan face to face interview (Wawancara berhadap-hadapan) dengan partisipan, mewawancarai mereka dengan telepon, atau terlibat dalam focus group interview (interview dalam kelompok tertentu) yang terdiri dari enam sampai delapan partisipan kelompok. Wawancara-wawancara seperti ini tentu saja memerlukan pertanyaan-pertanyaan yang secara umum tidak terstruktur (unstructured) dan bersifat terbuka (open minded) yang dirancang untuk memunculkan pandangan dan opini dari para partisipan.

Wawancara dilakukan dengan cara mempersiapkan terlebih dahulu persiapan yang dibutuhkan, yaitu informan, kriteria informan dan pedoman wawancara yang disusun dengan rapi dan terlebih dahulu dipahami peneliti. Wawancara perlu dilakukan berulang-ulang agar didapatkan data yang lebih lengkap. Hal-hal yang perlu diperhatikan sebelum melaksanakan wawancara:

- Menerangkan kegunaan serta tujuan dari penelitian.

- Menjelaskan alasan mengapa informan terpilih untuk diwawancarai.

- Menentukan strategi dan taktik wawancara.

- Mempersiapkan pencatat data wawancara.

\section{Teknik Analisis Data}

Analisis dalam penelitian kualitatif dilaksanakan pada saat pengumpulan data berlangsung dan setelah selesai di lapangan. Teknik yang digunakan adalah dengan menggunakan teknik analisis data Miles \& Huberman (2009: 16-20). Menurut keduanya, bahwa aktivitas dalam analisis data kualitatif dilakukan secara interaktif. Analisis data kualitatif merupakan upaya yang berlanjut, berulang dan terus-menerus. Masalah reduksi data, penyajian data dan penarikan simpulan menjadi keberhasilan secara berurutan sebagai rangkaian kegiatan analisis yang saling susul menyusul.

\section{HASIL DAN PEMBAHASAN}

Dari hasil observasi dan pengambilan data di beberapa desa wilayah Kecamatan Petir Kabupaten Serang, peneliti mendapatkan analisis sebagai berikut.

Berdasarkan observasi lapangan dan wawancara, dapat diketahui bahwa pemberdayaan lahan pertanian dan perkebunan di wilayah Kecamatan Petir sudah berjalan namun belum optimal. Hal ini dapat ditunjukkan dari beberapa contoh desa yang diambil bahwa masih terdapat kekurangan dan hambatan-hambatan yang dialami masyarakat di Kecamatan Petir. Hambatan tersebut berasal dari alam maupun bukan dari alam (faktor manusia itu sendiri). Adapun permasalahan yang saat ini dialami di antaranya:

1) Masyarakat umumnya mengandalkan air hujan (tadah hujan) untuk mengairi lahan persawahan. Pemerintah daerah sudah memprogramkan pembangunan irigasi namun baru sebatas beberapa desa saja.

2) Kualitas tanah di Kecamatan Petir sebagian besar merupakan lahan kritis sehingga untuk optimalnya hasil pertanian dan perkebunan harus dilakukan pengolah terlebih dahulu melalui beberapa tahapan.

3) Masih banyak lahan lahan yang belum dimanfaatkan untuk peningkatan pertanian dan perkebunan. Hal ini berkaitan dengan mahalnya modal yang harus dikeluarkan untuk pengolahan lahan sesuai dengan kondisi alam yang ada dan penghasilan yang diperoleh oleh masyarakat.

\section{Pembahasan}

Pembahasan hasil penelitian ini dengan menggunakan teori analisis SWOT (strength, weakness, opportunities, dan threats)yang diharapkan dapat menghasilkan strategi 
pemberdayaan lahan pertanian dan perkebunan yang tepat sesuai dengan tujuan awal.

\section{- Strengths (Kekuatan)}

Strength (Kekuatan) adalah kondisi kekuatan yang terdapat dalam sebuah organisasi, proyek, atau konsep yang ada. Kekuatan yang dianalisis merupakan faktor internal dalamsebuah organisasi.Pemerintah daerah memiliki Strength atau kekuatan dalam pemberdayaan pengembangan lahan pertanian dan perkebunan agar dapat berjalan efektif dan efisien. Seperti yang diungkapkan oleh Camat Kecamatan Petir

"Pemerintahan dalam hal ini kami Kecamatan Petir haruslah memiliki dasar terlebih dahulu dan setelah itu kami dapat melakukan pemberdayaan bagi lahan pertanian dan perkebunan bagi Kecamatan Petir". (senin, 23 April 2018). Selama ini pemerintah daerah baik kecamatan maupun desa telah bersinergi dan bekerja sama dengan UPTD. Pertanian dan Perkebunan Kec. Petir dan memonitor hasil pelaksanaan kegiatan tersebut.

Kelebihan dari wilayah ini dalam permberdayaan pertanian dan perkebunan terletak pada luas wilayah yang telah diprogramkan oleh Pemerintah daerah maupun dari Dinas Pertanian. Pernyataan tersebut didukung dengan pernyataan yang disampaikan oleh Staf Bagian Penyuluhan UPT Pertanian Kecamatan Petir pada Senin, 23 April 2018 bahwa:

"Lahan pertanian dan perkebunan yang dimiliki oleh Kecamatan Petir ini cukup besar dan jika dikembangkan dan dikelola dengan baik tentunya akan mendatangkan keuntungan yang besar bagi kecamatan, oleh karena itu perlunya dilakukan pemberdayaan bagi lahan pertanian dan perkebunan pada Kecamatan Petir".
Berdasarkan hasil wawancara diketahui bahwa Pemerintah memiliki peran tersendiri dari segi regulator untuk bisa mengembangkan lahan pertanian dan perkebunan yang merupakan salah satu sumber mata pencaharian dari penduduk Kecamatan Petir. Mendorong masyarakat agar dapat bersinergi dengan programprogram yang telah direncanakan. Dilakukan juga tinjauan terhadap kelompok tani yang ada di Desa Padasuka dan Kubangjaya, bahwa gabungan kelompok tani dari setiap desa umumnya telah aktif di dalam berorganisasi di mana dalam setiap langkah yang diambil dalam proses pertanian terlebih dahulu dilakukan musyawarah dalam menentukan startegi pertanian. Hal tersebut diungkapkan oleh kepala kelompok tani dari tiap-tiap desa yang ada.

"Kelompok tani di sini sudah mau aktif dalam berpartisipasi untuk menyumbangkan inspirasi dalam strategi pertanian yang akan dilaksanakan, misalnya dalam menentukan bibit tanaman yang akan ditanam, pemberian pupuk dan hal-hal mengenai pengolahan produksi pertanian" (Wawancara dengan Kepala Kelompok Tani Desa Padasuka pada 24 April 2018).

Dalam hal peningkatan sumber daya pertanian pihak UPTD juga membentuk tim penyuluhan yang sudah dapat dikatakan memadai dan memiliki kualitas. Hal ini terlihat dari program penyuluhan yang dilaksanakan secara terprogram dua minggu sekali ungkap Rinda selaku salah satu anggota tim penyuluh UPTD. Beliau mengatakan tim penyuluhan ini memiliki tugas menyosialisasikan program-program pertanian seperti program penanaman terpadu.

"Salah satu program yang pernah kami laksanakan adalah penyuluhan kepada petani mengenai penanaman cabe yang baik, di mana kami mengajarkan cara penanaman yang benar seperti jarak antarbibit tanaman, kedalaman 
bibit ditanam dan bagaimana cara pemeliharaannya sehingga diharapkan hasil dari panen cabe dapat lebih baik dan berkualitas". (Wawancara dengan Rinda selaku anggota Tim Penyuluhan UPTD pada 25 April 2018).

\section{-Weakness (kelemahan)}

Weakness (kelemahan) adalah keterbatasan atau kekurangan dalam sebuah organisasi, bisa dapat berupa keterampilan dan kemampuan yang menjadi penghalang untuk kinerja organisasi yang baik dan memuaskan. Kelemahan yang dianalisis merupakan faktor internal lingkungan tersebut. Pemerintah dalam pemberdayaan lahan pertanian yang masih memiliki beberapa kelemahan yang perlu diperbaiki dan kelemahan yang berada di Kecamatan Petir, seperti yang diungkapkan oleh Kepala Penyuluhan UPTD Pertanian Kecamatan Petir. Terutama dilihat dari beberapa bidang di antaranya Sumber Daya Alam, Sumber Daya Manusia dan Sumber Daya Ekonomi Masyarakat di Kecamatan Petir. Dari segi Sumber Daya Alam, khususnya adalah kebutuhan air dari lahan pertanian merupakan salah satu permasalahan yang dihadapi oleh pemberdayaan lahan pertanian yang terdapat di Kecamatan Petir. Ketika musim kemarau lahan pertanian tidak mendapatkan asupan air yang dibutuhkan sehingga sebagian besar lahan pertanian mengalami kekeringan dan gagal panen, sebagai contoh, yaitu kebutuhan air pada padi yang tinggi sehingga apabila musim berubah kemarau maka banyak petani yang gagal panen dikarenakan tidak adanya sumber air yang digunakan pada musim kemarau meskipun telah tersedia banyak irigasi desa namun apabila sumber air tidak ada maka irigasi yang tersedia tidak dapat dimaksimalkan fungsinya.

Hal tersebut sesuai dengan apa yang disampaikan oleh Kepala desa Kubangjaya sebagai salah satu desa yang memiliki irigasi desa yang cukup baik.
"Walaupun di Desa ini banyak irigasi desa dan kondisinya juga masih sangat baik karena baru diperbaiki dan renovasi oleh pemerintah atau dinas pekerjaan umum namun ketika musim kemarau datang bukan masalah irigasi tidak bisa mengaliri air dengan baik namun airnya itu dari mana datangnya itu tidak ada di sini tidak ada sumber air sehingga irigasi sebaik apa pun tapi kalau sumbernya tidak ada jadi apa yang mau dialiri" (Wawancara, 19 April 2018).

Kondisi ini juga didukung oleh pernyataan dari wawancara yang dilakukan dengan Sekretaris Desa Padasuka Bapak Encep pada 23 April 2018

"Jika musimnya seperti ini hujan terus maka kebutuhan air bisa cukup tapi beda kondisinya kalau musim kemarau di sini benar-benar tidak ada air paling hanya bergantung pada sungai kecil di sebelah utara desa itu juga hanya untuk desa ini untuk desa sekitar tidak bisa dimanfaatkan jadi sebagian besar kekeringan dan gagal panen."

Selain itu dari bidang sumber daya manusia, adanya pola pikir statis petani di Kecamatan Petir di mana mereka berpedoman pada tujuan untuk bercocok tanam adalah untuk makan sehingga memprioritaskan hasil pertanian padi atau beras untuk memenuhi kebutuhan pokok pangan masyarakat. Hal tersebut menyebabkan sebagian besar petani di wilayah Kecamatan Petir memaksakan untuk menanam padi, padahal yang kita ketahui bahwa padi memiliki usia yang panjang hingga mencapai usia panennya sehingga membutuhkan interval waktu yang lama oleh sebab itu para petani menggunakan pupuk urea atau kimia untuk mempersingkat masa tumbuh hingga memaksimalkan hasil panen tanpa memperhatikan dampak yang ditimbulkan dari pemakaian pupuk kimia atau urea tersebut terhadap tanah. Kondisi tersebut menjadi masalah utama yang 
dihadapi oleh penyuluh UPTD Pertanian Kecamatan Petir yang disampaikan langsung oleh penyuluh Ibu Rosinda.

"Kita sedang mencoba untuk mengubah mindset dan pola pikir masyarakat yang ingin praktis dan cepat dalam bertani khususnya pada padi, jadi petani itu lebih pilih paket pupuk kimia biar cepat panen dan juga sekarang pupuk urea itu disubsidi oleh pemerintah jadi harganya juga lebih murah dan mudah didapatkan karena pabriknya juga banyak" (Wawancara, 24 April 2018).

Karena interval yang dibutuhkan dari waktu semai bibit hingga panen terlalu lama dan sangat bergantung pada keadaan iklim, sehingga seorang petani hanya dapat panen padi paling banyak dua kali dalam setahun. Karena terkendala dengan pergeseran musim menuju musim kemarau dan jangka waktu pertumbuhan padi yang panjang hingga mencapai tiga bulan hingga mencapai batas panen. Untuk mengatasi hal tersebut kebanyakan petani hanya memandang praktis untuk mendapatkan keuntungan dan kemudahan dalam bercocok tanam sehingga mayoritas petani menggunakan pupuk kimia atau urea, padahal sebagaimana kita ketahui bahwa pupuk urea memang dampaknya membuat pertumbuhan tanaman semakin cepat namun dampak buruk yang ditimbulkan adalah bagi kesehatan struktur tanah, kandungan kimia yang ada dalam pupuk urea membuat struktur tanah di lahan pertanian Kecamatan Petir menjadi tidak sehat dan semakin lama akan menjadi struktur tanah gambut yang nantinya tidak dapat ditanami tanaman apa pun. Kondisi tersebut sangat memprihatinkan karena berdasarkan data Badan Pusat Statistik di Kecamatan Petir terdapat banyak lahan yang berpotensi menjadi lahan pertanian unggul yang bisa menghasilkan hasil panen yang tinggi. Tentunya kondisi ini dapat dikurangi dengan membatasi penggunaan pupuk kimia atau urea. Adapun dari kondisi Sumber Daya Ekonomi juga berdampak pada pengelolaan lahan yang diterapkan oleh seorang petani, di mana karena keterbatasan modal seorang petani lebih memilih menggunakan pupuk kimia atau urea yang mana telah mendapatkan subsidi dari pemerintah dibandingkan menggunakan pupuk organik atau pupuk kandang, meskipun tanpa mengeluarkan biaya namun ketersediaan pupuk organik sangat terbatas dikarenakan berasal dari makhluk hidup itu sendiri dan panen yang dihasilkan juga lebih besar dengan menggunakan pupuk kimia atau urea dibandingkan dengan pupuk organik. Hal tersebut didukung dengan pendapat penyuluh Unit Pelakasana Tugas Daerah Pertanian Kecamatan Petir Ibu Rinda.

"Karena keterbatasan ekonomi masyarakat, jadi masyarakat berpaling pada pupuk kimia dibanding pupuk organik karena lebih cepat terus hasil yang dicapai juga lebih banyak kalo dipakai pupuknya 2-3 hari langsung terlihat pertumbuhannya berbeda dengan pupuk organik yang membutuhkan waktu lebih lama dan hasil panen yang lebih sedikit' (Wawancara, 24 April 2018).

Seperti yang sudah diuraikan di atas dapat diketahui bahwa penyebab dari banyaknya lahan kritis di daerah Kecamatan Petir dikarenakan penggunaan pupuk kimia atau urea oleh petani yang berlebihan. Dengan menggunakan pupuk kimia atau urea petani berharap hasil panen akan lebih cepat, namun karena keterbatasan pengetahuan para petani sebenarnya hal tersebut lambat laun akan merusak stuktur tanah yang ada sehingga akan menjadi lahan kritis. Lahan kritis adalah kondisi di mana tanah dari lahan pertanian yang ada membutuhkan perbaikan tanah karena hilangnya keseimbangan stuktur tanah akibat penggunaan pupuk urea dan kimia yang berlebihan. Hal tersebut dapat diatasi dengan cara penggunaan pupuk organik atau pupuk kompos disertai pengairan yang cukup namun pada kasus lahan kritis di 
daerah Kecamatan Petir pengolahan lahan kritis ini membutuhkan biaya atau modal yang besar.

\section{- Oppurtunity (Peluang)}

Salah satu peluang terbesar dari pemberdayaan lahan di antaranya datang dari adanya partisipasi aktif dari kelompok tani dan gabungan kelompok tani, peran pemerintah daerah, serta masih terdapatnya lahan tidur yang dapat digunakan sebagai lahan pertanian maupun perkebunan yang dapat menghasilkan untuk menunjang kehidupan masyarakat khususnya di Kecamatan Petir. Hal tersebut didukung oleh pernyataan dari penyuluh UPTD Ibu Rosinda:

“Di Kecamatan Petir ada beberapa kelompok petani yang aktif dan gabungan kelompok petani yang aktif dan hasilnya juga dapat dilihat sendiri untuk kelompok petani yang aktif dan mau membuka pikirannya kepada kami" (Wawancara, 24 April 2018).

Terdapat sebuah organisasi yang dinamakan Kelompok Tani atau Poktan dan Gabungan Kelompok Tani atau Gapoktan, di setiap desa memiliki Poktan dan Gapoktan, tugas dan fungsi dari organisasi tersebut adalah mengayomi dan sebagai kepanjangan tangan dari pemerintah khususnya lingkup kecamatan untuk menyampaikan programprogram yang dicanangkan oleh pemerintah. Selain itu ketersediaan lahan kosong yang belum jelas peruntukannya masih banyak terdapat di Kecamatan Petir serta banyak lahan perkebunan heterogen yang ditanami berbagai macam tanaman membuat banyak potensi yang terdapat di Kecamatan Petir itu sendiri. Apabila lahan tidur dan lahan perkebunan mendapatkan perhatian yang lebih dan dapat lebih fokus untuk pemberdayaannya, kemungkinan besar tercapainya hasil panen yang maksimal dan kesejahteraan rakyat dapat dicapai. Kondisi tersebut dapat direalisasikan dengan menerapkan lahan perkebunan homogen dan memaksimalkan lahan tidur untuk ditanami komoditas homogen guna memaksimalkan hasil panen di Kecamatan Petir. Untuk sebuah lahan tidur dan lahan perkebunan hanya ditanami sejenis tanaman saja sehingga tidak merusak struktur tanah dan perawatan yang sama akan memudahkan dalam pengelolaan tanaman oleh pemiliknya. Selain itu, untuk menunjang otonomi daerah sehingga setiap daerah Kecamatan terdiri dari Desa yang memiliki ciri khas sebagai penghasil atau produksi panen tertentu. Hal tersebut telah diterapkan oleh Kabupaten Malang di mana setiap lahan digunakan hanya untuk tumbuhan yang sejenis sehingga hasilnya juga dapat maksimal dan juga menarik untuk dijadikan sebuah agrowisata. Kondisi ini merupakan hal yang ingin diterapkan oleh pihak penyuluh dari UPTD Pertanian Kecamatan Petir, sebagaimana yang diungkapkan oleh Ibu Rinda dalam kesempatan wawancara yang kami lakukan:

"Tujuan kami adalah untuk menyejahterakan masyarakat, yaitu salah satunya dengan cara menanamkan cara yang efektif untuk pengelolaan lahan pertanian dan menerapkan lahan perkebunan homogen sehingga masyarakat dapat lebih terfokus pada satu jenis tanaman yang akan di produksinya untuk bidang perkebunan sedangkan dari segi pertanian melalui cara bercocok tanam yang benar dan pengelolaan lahan yang benar faktor iklim dan cuaca dapat diperkecil kemungkinannya dalam mengganggu stabilitas hasil panen, sehingga pengelolaan lahan pertanian dan perkebunan dapat lebih maksimal" (Wawancara, 24 April 2018).

Seperti yang kita ketahui bahwa lahan pertanian di wilayah Kecamatan Petir dapat dikatakan luas dan memiliki potensi yang besar dalam hasil produktivitasnya sehingga dapat mewujudkan swasembada pangan di Kecamatan Petir. Hal tersebut tentunya membutuhkan sinergitas dari setiap pihak yang ada dalam hal ini baik pemerintah 
daerah dan kelompok tani sehingga pengolahan lahan pertanian yang ada dapat maksimal sehingga dapat meningkatkan hasil produktivitas pertanian guna mewujudkan swasembada pangan di Kecamatan Petir.

Dalam mewujudkan swasembada pangan tersebut secara tidak langsung akan menyerap banyak tenaga kerja. Mulai dari mengolah lahan yang ada, di mana kita ketahui bahwa di Kecamatan Petir banyak terdapat lahan kritis sehingga untuk mengolah lahan tersebut tentunya membutuhkan banyak tenaga kerja. Selain itu jika konsep swasembada pangan tersebut dapat terealisasikan tentunya akan menarik minat banyak penduduk untuk beralih profesi di bidang pertanian sehingga mengurangi angka pengangguran di wilayah Kecamatan Petir.

\section{- Threat (Ancaman)}

Sebagian besar daerah pertanian di wilayah Kecamatan Petir belum memiliki sumber air sendiri, sehingga pada musim kemarau meskipun telah tersedia banyak irigasi desa namun apabila sumber air tidak teraliri, maka irigasi yang tersedia tidak dapat dimaksimalkan fungsinya. Faktor iklim yang berubah juga dapat menjadi salah satu ancaman, saat ini seperti yang kita alami bahwa cuaca yang diprediksi oleh BMKG sering kali berbeda dengan kenyataan yang terjadi sehingga cuaca yang sulit untuk diprediksi ini tentunya menjadi salah satu faktor penghalang mengingat ketergantungan pertanian Kecamatan Petir pada musim penghujan di mana aliran irigasi dapat dialiri air hujan mengingat belum adanya sumber air yang dimiliki masing-masing kelompok pertanian di daerah Kecamatan Petir.

Dalam pengolahan lahan di Kecamatan Petir mayoritas Gabungan Kelompok Tani yang ada masih menggunakan cara tradisional dalam pengolahan lahan pertanian yang ada. Mayoritas petani masih menggunakan kerbau untuk membajak lahannya padahal sudah ada teknologi yang lebih efektif dan efisien yang dapat digunakan. Berdasarkan survei lapangan yang dilakukan salah satu Gapoktan di Desa Padasuka Kecamatan petir sudah menggunakan teknologi traktor dalam mengolah lahan pertanian, namun terdapat kendala yang menjadi ancaman dalam proses pertanian di Desa tersebut, yaitu faktor keamanan yang masih kurang, karena tingkat pencurian peralatan yang digunakan untuk pengolahan lahan masih sering terjadi.

"Kalauberkaitan denganfactorkeamanan dan pemanfaatan teknologi maju Desa Padasuka ini, kami telah mendapat dukungan dari Dinas Pertanian, yaitu Traktor. Namun terdapat oknum yang berusaha mencuri traktor tersebut, akibatnya traktor tersebut tidak dapat digunakan sampai saat ini karena masih dijadikan barang bukti di Polres Serang." (Wawancara dengan Kepala Gapoktan Desa Padasuka, 24 April 2018).

\section{SIMPULAN}

Berdasarkanhasilpenelitian dantemuantemuan di lapangan, maka penyimpulan akhir tentang strategi pemberdayaan lahan pertanian dan perkebunan guna meningkatkan kesejahteraan masyarakat di Kecamatan Petir Kabupaten Serang adalah sebagai berikut.

Faktor kekuatan adalah gabungan kelompok tani di tiap desa yang sudah aktif, kualitas dan kuantitas tim penyuluh yang ada di Kecamatan Petir memadai dan berkualitas, setelah beberapa bulan program pemerintah daerah guna meningkatkan pertanian, dan banyaknya lahan tidur yang dapat dimanfaatkan seoptimal mungkin pertanian dan perkebunan yang siap diolah.

Faktor kelemahan antara lain mengandalkan air hujan sepenuhnya untuk pengairan sawah, kondisi lahan sebagian besar adalah lahan kritis, membutuhkan modal awal yang besar untuk pengolahan lahan, dan kurangnya pengetahuan dan kompetisi petani. 
Faktor peluang antara lain menjadikan kecamatan Petir sebaga agrobisnis dan agrowisata, dapat mewujudkan swasembada pangan, dapat menyerap tenaga kerja lebih banyak dan meningkatkan kesadaran dan keterampilan petani.

Faktor ancaman antara lain iklim yang sulit diprediksi, tingkat pencurian peralatan untuk pengolahan lahan meningkat, pengolahan lahan masih menggunakan cara tradisional dan perkembangan industri di Kabupaten Serang meningkat sehingga banyak usia produktif melakukan urbanisasi dan lebih memilih menjadi buruh pabrik bahkan menjadi TKI.

\section{SARAN}

Berdasarkan simpulan mengenai strategi pemberdayaan lahan pertanian dan perkebunan guna meningkatkan kesejahteraan masyarakat di Kecamatan Petir Kabupaten Serang maka diberikan saran dari hasil penelitian untuk meningkatkan pemberdayaan lahan pertanian dan perkebunan yang belum optimal di wilayah Kecamatan petir, sebagai berikut.

Mencanangkan/menerapkan lahan homogen untuk perkebunan di setiap desa, mengoptimalkan pemberdayaan lahan pertanian yang ada melalui program yang telah disediakan oleh pemerintah, mengelola lahan tidur pertanian dengan cara menyerap tenaga kerja yang ada dengan sistem bagi hasil, dan melaksanakan program penyuluhan dan pelatihan intensif bagi masyarakat usia produktif di Kecamatan Petir.

Pembuatan embung dan irigasi agar bisa dijadikan sebagai sarana penampungan air dan tepat wisata/perikanan, pengelolaan tanah dengan cara penggunaan pupuk organisasi, mengajukan bantuan subsidi sesuai dengan kebutuhan, menggunakan teknik sistem bedeng permanen (menggunakan air sekitar setengah bagian dari kebutuhan sistem tergenang tanah tak diolah/diolah minimum).
Menentukan jadwal penanaman yang bekerja sama dengan BMKG, penyuluhan kamtibmas, menerapkan teknologi dalam pengolahan lahan pertanian dan perkebunan, melakukan hak paten lahan jalur hijau untuk menstabilkan lingkungan hidup di Kecamatan Petir.

Mengefektifkan atau mengefisiensikan penggunaan air pada musim hujan untuk menanam padi, melaksanakan program penanaman terpadu, mengajukan permintaan peralatan pertanian berteknologi maju, memberikan kesadaran pada masyarakat khususnya usia produktif untuk tetap melestarikan pertanian dan perkebunan melalui penyuluhan pada aparat desa atau UPTD Pertanian.

\section{DAFTAR PUSTAKA}

Adi, Isbandi Rukminto, 2008. Intervensi Komunitas: Pengembangan Masyarakat Upaya Pemberdayaan Masyarakat. Jakarta: PT Raja Grafindo persada.

Abdurachman et al. 2008. Biologi Kelompok Pertanian, PT. Grafindo Media, Jakarta

Lasmahadi, 2002. Sosiologi Perdesaan: Mencari suatu Strategi Pembangunan Masyarakat Desa Berparadigma.

Mubyarto dan Santosa 1993. Modernisasi Dan Perubahan Sosial Masyarakat dalam Pembangunan Pertanian Suatu Tinjauan Sosiologi. Medan: Sosiologi FISIP USU

Minardi, 2009 Optimalisasi Pengelolaan Lahan Kering untuk Pengembangan Pertanian Tanaman Pangan. eprints.uns.ac.id

Notohadinegoro, 2000 Diagnostik Fisik Kimia dan Hayati Kerusakan Lahan.

Stoner J., Freeman R., Gilbert JR, (2005), Management, Sixth edition

Sugiyono, 2014, Memahami Metode Penelitian Kualitatif. Bandung: Alfabeta.

Sumodiningrat. 2000. Pengantar Ilmu Pertanian. Jakarta: Raja Grafindo Persada.

Sitorus, 1998 Evaluasi Sumber Daya Lahan. Bandung: Tarsito 